\title{
EFFECT OF SOIL REPLACEMENT ON COLLAPSIBILITY OF FOOTING RESTING ON CALCAREOUS SAND- A PROTOTYPE STUDY
}

\author{
Waad Abdulsattar Zakaria \\ Assistant Professor, College of Engineering, Diyala University \\ E-mail: waadzakariya@yahoo.com \\ (Received: 25/11/2013; Accepted:9 /1/2014)
}

\begin{abstract}
Soil replacement technique is not a new method to improve a soil stratum possessing poor strength properties. Before, such a problem of facing a location with weak soil properties is simply solved by changing that spot of estate by another one. Nowadays, such a proposal is no longer valid as a solution since the finance of real estates is rising considerably so that altering a location to the favor of other is not a choice. Calcareous soils are soils rich of calcium carbonate which occur manly in the semiarid subtropics for both hemispheres. This soil is one of the famous collapsible soils similar to the well-known gypseous soils. It has very good strength properties when dry, but once wetted it undergoes large and almost instantaneous settlement, potential collapse of productivity, even if there is no additional load applied on it. This research is concerned in studying the effect of soil replacement technique in reducing collapse settlement. A laboratory prototype model is used in study using SW soil mixed with different percentages of calcium carbonates, and gradual replacement of calcareous soil with sand is carried out in terms of width of footing B. Each model is leached for continuous seven days, and time-settlement data are recorded. This is done again for different percentages of calcium carbonate ratios mixed with sand. Laboratory tests revealed that the degree of improvement in terms of settlement for replacing $B / 2$ depth by sand is 0.36 ( $\mathrm{B}$ is footing width), that for replacing $\mathrm{B}$ is 0.65 , for replacing $2 \mathrm{~B}$ is 0.88 , and for replacing $3 \mathrm{~B}$ is 0.92 . The amount of $\mathrm{CaCO}_{3}$ in soil does not affect the degree of improvement observed. An empirical formula is derived using finite differences for relating degree of improvement with depth of soil to be replaced.
\end{abstract}

Key Words: Calcareous sand, soil replacement, collapsibility, improvement. 


\section{SOME ASPECTS ON CALCAREOUS SOILS IN WORLD}

Soil collapse forms a major hazard in large parts of eastern Canada, the United States, Eastern Europe, China and southern Africa. The sediments involved include young marine clays and lake sediments, wind-deposited materials (loess and some sands), volcanic ash, and some residual soils. Human activities continue to increase in regions underlain by collapsible soils, so that the hazards posed are increasing in both relative and absolute terms. Collapsible soils are metastable. A granular material with angular particles compacted on the dry side of optimum can form a structure which is capable of further densification. This is a phenomenon known from the full particle size range - from clays to coarse rock aggregates. However, the classic collapsible soils are natural materials in which particle type and sedimentation mechanism combine to produce collapsibility. The collapsing soils problem is exacerbated by a paucity of descriptive terms, (Olsen and Leonard, 1982) ${ }^{(1)}$.

In the context of soil problems, calcareous soils are soils in which a high amount of calcium carbonate dominates the problems related to engineering land use. They are characterized by the presence of calcium carbonate in the parent material and in layers of secondary accumulation of carbonates (usually $\mathrm{Ca}$ or $\mathrm{Mg}$ ) in excess of $15 \%$ calcium carbonate equivalent and at least 5\% more carbonate than anderlying layer (according to an agricultural bases), (Chaney and Slomim, 1982) ${ }^{(2)}$. The secondary calcium carbonate are formed under arid or semi-arid climatic conditions when the carbonate concentration in the soil solution remains high. Accumulation starts in the fine and medium sized pores at the surface of contact between the soil particles. This accumulation may by rather concentrated in narrow zone or more dispersed, depending upon the quality and frequency of rainfall, topography, soil texture and vegetation. In some soils the calcium carbonate deposits are concentrated into layers that may be very hard and impermeable to water called "Caliche". These Caliche layers are formed by rainfall (at nearly constant annual rates) leaching the salts to a particular depth in the soil at which the content is so low that the carbonates precipitate. They are also formed by salt moving upward from a water table, mainly caused by irrigation, and precipitate near the top of the capillary zone. The total extent of calcareous soils is estimated at 800 million hectares worldwide, as can be seen in Table (1), mainly concentrated in arid or Mediterranean climates. However, the total area of calcareous soils is difficult to estimate and Figure (1) shows such estimated region, (FAO/AGL, 2000) (3).

On the other hand, according to Xin-Zhi et al, (2011) ${ }^{(4)}$ calcareous sand is an accumulation of pieces of carbonate material, it usually originates from reworked shell fragments and skeletal debris of marine organism and their complicated properties have been a major challenge to the geotechnical engineers since 1960 `s 
Olsen and Leonard (1982) ${ }^{(1)}$ stated that common test procedures available for determination of $\mathrm{Ca}^{+2}$ concentration are, AAS, (the atomic absorption spectrophotometry); EDTA, (ethylendiamine tetra acetic acid); and the calcium-specific ion electrode. On the other hand, the test procedure available for determination of $\mathrm{CO}_{3}{ }^{-2}$ concentration are;

1. Vacuum distillation and titration method

2. Gravimetric methods

3. Acid-soluble weight loss method

4. Volume calcimeter method

5. Pressure calcimeter method

6. Gravimetric method for loss of carbon dioxide

7. Acid-neutralization method

From soil mechanics principles, there are two aspects in preparing soil for testing, that is, to use natural soil or to use soil which is prepared in laboratory. The first soil type is, certainly, very realistic and results obtained reflect close-to-behavior of problem. However, the second type is prepared in laboratory and it is only sand mixed with powder of calcium carbonate. The remolded soil does not retain its fabric structure. The first type of soil preparation has some amount of disturbance, while the other is totally remolded soil or more precisely a soil mixture. The fabric structure and behavior between the two is totally different. In this study, nevertheless, the intension is to use different amounts of $\mathrm{CaCO}_{3}$ contents (as mixed in percentages with sand) thus the second aspect of soil preparation is going to be used here.

\section{SOIL REPLACEMENT METHOD IS ONE OF SOIL IMPROVEMENT TECHNEQUES}

It is one of the oldest and in the same time simplest methods and it is simply to remove soil possessing bad strength properties and replace by a better one. Soils that will have to be replaced include contaminated soils, organic soils, or one of the problematic soil. The method is usually practical only above the ground water table. Some engineers feel that unless the depth of replacement is small, it is money and time consuming method!. This is because the method needs large potential of equipment and the soil brought for replacement should be not far away. On the other hand, the soil which has been laid down must receive heavy compaction to bring it to the desired strength properties just designed for. In spite of these drawbacks in certain situations the method may be the only method useful and effective especially in the case on the existence of collapsible soils and that problematic soil layer is small. The decision of what proper method to use in order to bring the soil properties to the 
desired ones depends on large number of variables, and such a case needs a feasibility study.

Thus, it is not true that a specific method in concern is all ways the better and the best.

In contrast to that, many others went for local stabilization of such soils. Olsen an Leonard (1982) ${ }^{(1)}$ proved experimentally that unconfined compressive strength shows an increase of 400 percent with time (120 days) over specimens tested immediately after compaction for calcareous soils, while Al-Amoudi (1994) ${ }^{(5)}$ proved that stabilizing natural saline-Sabkha soil by compaction and cement addition results in high strength gain with time and proved to have a potential use in civil engineering construction. Similar results are reached by Yahia et al (2011) ${ }^{(6)}$ in stabilizing Sabkha sand in Sultanate of Oman by compaction and cement addition. Stepho $(1989)^{(7)}$ showed experimentally that both Portland cement and lime in quantities as little as $5 \%$ by weight improves saline soil behavior significantly while dynamic consolidation with sand pillars seems to give satisfactory results in Gadget timed out while loading. During their research work of plate load test on calcareous sand Xin-Zhi $(2011)^{(4)}$, the deformation modulus of calcareous sand increases with the increase of relative density (i.e., if relative density increases from $44 \%$ to $56 \%$ deformation modulus increases from 1.35 MPa to $2.51 \mathrm{MPa}$ or if relative density increases form $50 \%$ to $68 \%$ deformation modulus increases from 2.51-7.05 MPa. Stark et al, (2012) ${ }^{(8)}$ stated that carbonate sands (calcareous sand) have higher friction angle (carbonate 31-37\%; quartz 31$32^{\circ}$ ) and higher void ratio (carbonate 1.1-1.4; quartz 0.81-0.93) than their siliceous counterparts. They have attributed that to the higher angularity or the coral-derived particles. Rezaie et al $(2012)^{(9)}$, in their study on collapsible soils in Iran, showed that among the many methods of improving the collapsible soils, preflooding and loading together is found to be useful in stabilization of such soils,

\section{MODELING OF SOIL IN TESTING AND RESULTS}

If it is required to solve induced stresses in soil upon loading then the problem stands for the reliability of stress calculation using the theory of elasticity which gives a variation of about $20-30 \%$ according to Das $(2008)^{(10)}$ or $(+$ or $-25 \%$ ) and even more for Lambe and Whitman $(1979)^{(11)}$. Author feels that presence of calcareous materials in soils with its collapse potential property may change these numbers sense soil would deviate in its behavior to the non-elastic side. On the other hand, Wilun and Starzewski (1975) ${ }^{(12)}$ stated that within the predicted range of working loads (considerably smaller than the loads which produce plastic deformation of soils) it can be assumed that the determination of soil mass are linearly related to the stress provided by loads. The FEM is now widely used for calculation stresses and displacements, Craig $(2004)^{(13)}$, the method enables the soil to be treated as 
either non-homogeneous or an isotropic elastic material. Author believes that numerical methods give good results provided that strength properties of soil are obtained accurately, the case which is difficult in soil approach.

There are too many possibilities for choosing the figures of the setup, since there are many provisions for the size of it; that is, it should not be large to be not practical and not too small to lose the sense of simulation. Figure (2) shows the details of the setup used in the preparation and testing of laboratory models. In order to make best possible control throughout testing, technically, two stiff-hard plastic containers of different size are used. The smaller container has a diameter of $300 \mathrm{~mm}$ while the bigger has a diameter of $500 \mathrm{~mm}$ and both with depth of $600 \mathrm{~mm}$. In the smaller container calcareous sand is compacted to a dry density between $15-17 \mathrm{kN} / \mathrm{m}^{3}$, depending on the amount of calcium carbonates, with molding water content between 3-5\%. Each sample is given same compacting energy for each layer is compacted using special tamping rod. The reason for using calcareous sand is that sand has high coefficient of permeability. The time for leaching a laboratory model is much reduced compared by using other type of calcareous soil.

The steps of modeling and testing are as follows:

1. A layer of $30 \mathrm{~mm}$ of dry pure-clean sand is laid down at bottom of small container. This layer of sand is considered essential for the drainage of the calcareous soil during leaching. Drain holes are made through the bottom of both plastic containers in order to let water to drain out of them. So no water is perched into containers.

2. The calcareous sand (having a $\mathrm{CaCO}_{3}$ of $30 \%$ of sand by weight) is prepared outside the container and mixed thoroughly with $3-5 \%$ of water. The calcareous sand mixture is pored into the container in layers, each of about $80-100 \mathrm{~mm}$ and are compacted using the standard Proctor tamper. Eventually the thickness of the calcareous sand in container is variable but in the case of no soil replacement it ends eventually to a thickness of $500 \mathrm{~mm}$. A small steel circular thick plate having diameter of $50 \mathrm{~mm}$, representing the prototype footing, is placed onto the surface of soil and in the center of the small container. The steel plate has a small groove in its center for placing the loading frame shaft. No eccentric loading is allowed in test to minimize tilting of footing, since the circular footing can be totally fixed with the loading shaft through welded bolt.

3. The small plastic container with the calcareous sand prepared into it, is then placed into bigger container and both are placed near a large steel table. The steel loading frame is fixed to the steel table and the magnetic holder of dial gauge is attached to the table as well. The loading frame is placed on the circular steel plate (into the groove of footing) with weights attached on it as to supplement a constant and permanent stress on soil of 
$50 \mathrm{kPa}$ (which is rather low). Author believes that this stress is chosen as a domestic engineering facility may apply a similar stress on foundation. The dial gauge is leveled to an initial reading representing the zero point, and readings for settlement are begun to be recorded.

4. Now, water is added carefully to the small container, and the period of leaching for seven continuous days is begun. Settlement readings are recorded until the settlement of footing is nearly stopped or very small. The big container is provided with drain holes, as mentioned before, that can be controlled as to be used for both soaking and leaching processes. In this research only leaching is done, since in nature, process of soil leaching is believed the most predominant and close to reality.

5. After that a second container is prepared again as mentioned before but a layer of thickness $(\mathrm{B} / 2)$ is replaced by pure sand (with no calcium carbonate) as to have a soil replacement depth of $\mathrm{B} / 2$ in terms of footing width $\mathrm{B}$. This layer of sand is compacted, as well, in layers in a similar condition to the original calcareous soil. The testing procedure is repeated as said before. The layer thickness of soil replacement is increased to $\mathrm{B}, 2 \mathrm{~B}$, and $3 \mathrm{~B}$, and the whole tests are repeated again with same procedure. After finishing all those tests for $\mathrm{CaCO}_{3}$ content of $30 \%$, the steps are all repeated for other two ratios, namely, 50 and $70 \%$.

The angle of shearing friction $\varphi$ obtained using the direct shear box is as follows, please care for Table (2):

Sand alone $=35$ degrees, (an average of three tests), sand with $50 \%$ of $\mathrm{CaCO}_{3}$ by weight=about 33 degrees, tested on dry bases, (an average of six tests with too much scattering).

The sand used itself is classified as SW and brought out from Al-akheidher \Kerbala, but contains 4\% fines (passing 200 sieve). No Proctor test is conducted, but the soil in each container is rather heavily compacted, giving each container an equal compacting energy regardless of dry unit weight. All laboratory test conducted confirm to Bowles (1981) ${ }^{(14)}$.

Now going to test results, Figure (3) shows typical time-settlement curves recorded for a calcium carbonates content of $50 \%$ by weight of dry soil and for different soil replacement depths in terms of footing width B. Table (3) is the numerical data for the curves in Figure (3). To follow the symbols used, it is listed here.

$\mathrm{S}=$ settlement measured of footing.

$\mathrm{B}=$ width or diameter of the footing. Here it is $50 \mathrm{~mm}$.

$(\mathrm{S} / \mathrm{B})_{\mathrm{u}}=$ ratio of measured settlement to width of footing for untreated calcareous soil. 
$(\mathrm{S} / \mathrm{B})_{\mathrm{B} / 2}=$ ratio of measured settlement to width of footing for model where calcareous soil directly underneath footing is replaced by sand to depth of $B / 2$.

$(\mathrm{S} / \mathrm{B})_{\mathrm{B}},(\mathrm{S} / \mathrm{B})_{2 \mathrm{~B}},(\mathrm{~S} / \mathrm{B})_{3 \mathrm{~B}}=$ same as $(\mathrm{S} / \mathrm{B})_{\mathrm{B} / 2}$ but depths of soil replaced by sand are $\mathrm{B}, 2 \mathrm{~B}, 3 \mathrm{~B}$ respectively.

Author believes that instead of showing time-settlement curves in terms of nominal settlement alone, i.e. in millimeters, it is better to show that in normalized form that is the settlement in terms of footing width $(\mathrm{S} / \mathrm{B})$. This provides more comprehensive look of the general behavior than using pure numerical data although the trend is the same. For this reason all analyses relating settlement in study are presented in terms of $(\mathrm{S} / \mathrm{B})$ ratios. The time-settlement curves for $\mathrm{CaCO}_{3} \%$ content of 30 and 70 are not presented so they look similar to those of $50 \%$ shown in Figure (3), i.e. same trend of behavior but with different magnitudes. Table (4) show the final (S/B) values measured after seven days of leaching, and as mentioned earlier settlement recording continues for all models until the measured settlement stops or at least nearly so, i.e. time-settlement curve levels off. In all cases of models no settlement is observed over seven days of leaching and it level off before that period, so seven days for each model is enough to have the final (or eventual) S/B values.

Figure (4) show the drawn data for Table (4). It represents the final (S/B) ratios observed versus depths of soil replacement for three percentages of $\mathrm{CaCO}_{3} \%$. The higher the depth of calcareous soil replaced, the lower S/B value measured. Also, the higher the $\mathrm{CaCO}_{3} \%$ content the higher the S/B ratio measured. Now in returning to Table (4) it is observed an $(\mathrm{S} / \mathrm{B})$ u value for $70 \%$ of $\mathrm{CaCO}_{3}$ to be 0.38 which represents maximum settlement ratio observed in table. In fact, this is very high value and author doubts that any domestic structure can withstand such high settlement. And to envision what is the meaning of such ratio we consider a footing having two meters of width. Then the settlement that may take place will be $0.38 \times 2000=760 \mathrm{~mm}$ or about 30 inches and this indeed is very high amount. Another problem imposes itself here is that this type of settlement is instantaneous (potential collapse). It is quite different in type from the long term settlement such as the consolidation settlement or the secondary compression or the large settlement of the organic soils (such as peat and muskegs). The collapse settlement is by far more dangerous and causes greater distress than the consolidation settlement even if they were of equal magnitude. If settlement takes place through long period of time, i.e. years or decades for instance, the structure may have some time to "readjust" or distribute the induced stresses resulting from settlement. That is why the instantaneous or collapse settlements are more to concern and pay attention than the consolidation one. On the other hand, the smallest settlement ratio measured is $(\mathrm{S} / \mathrm{B})_{3 \mathrm{~B}}$ for 

$\mathrm{B}=2 \mathrm{~m}$. It is rather a small value compared with $760 \mathrm{~mm}$ before.

Table (5) shows a modification to Table (4). It represents the degree of improvement obtained versus different depths of soil replacements and for three $\mathrm{CaCO}_{3} \%$ contents, namely, 30, 50, and 70, while Figure (5) shows these data drawn to a suitable scale. By degree of improvement "DOI" we mean as follows

$$
\mathrm{DOI}=\left[(\mathrm{S} / \mathrm{B})_{\mathrm{u}}-(\mathrm{S} / \mathrm{B})_{\mathrm{t}}\right] /(\mathrm{S} / \mathrm{B})_{\mathrm{u}}
$$

And as before $(\mathrm{S} / \mathrm{B})_{\mathrm{t}}=(\mathrm{S} / \mathrm{B})_{\mathrm{B} / 2},(\mathrm{~S} / \mathrm{B})_{\mathrm{B}},(\mathrm{S} / \mathrm{B})_{2 \mathrm{~B}}$, or $(\mathrm{S} / \mathrm{B})_{3 \mathrm{~B}}$, it simply means the treated (S/B) by soil replacement. Roughly speaking, it can be said by observing Figure (5) that the percentage of $\mathrm{CaCO}_{3}$ does not affect the degree of improvement DOI. For soil replacement of $(\mathrm{B} / 2)$ the DOI value ranges between 0.33 and 0.40 ; for soil replacement of depth $\mathrm{B}$, DOI ranges between (0.6 to 0.7 ); for $2 \mathrm{~B}$, from 0.88 to 0.90 ; and for $3 \mathrm{~B}$ about 0.93 . Author believes that the most practical depth of soil replacement ranges between $\mathrm{B} / 2$ to about 2B. A depth for soil replacement of $3 \mathrm{~B}$ is hard to follow and may require large finance with heavy equipment unless footing width is rather small.

In order to make use of Figure (5) mathematically, the data relating to figure which is shown in Table (5) is transformed onto a useful equation rating the DOI value with the depth of soil replaced in terms of footing with B. In deriving this equation, finite differences approach is used in order to reach to the following formula

$$
\mathrm{DOI}=\mathrm{z}^{3} / 18.0723-0.427 \mathrm{z}^{2}+1.123667 \mathrm{z}-0.102
$$

where $\mathrm{z}$ here belongs to depth of soil replacement in terms of $\mathrm{B}$. Te value of $\mathrm{z}$ is best applicable for numerical values between 0.5 and 3. And as this study is "qualitative and not quantitative", the formula mentioned above can indeed be used as a guide in predicting the degree of improvement one can get if he is to replace $z$ depth of calcareous soil by sand underneath the footing. It is worth to mention that from Figure (5), the amount of $\mathrm{CaCO}_{3} \%$ in soil does not have appreciable effect on the degree of improvement, i.e. the degree of improvement, in an approximate way, does not depend on the amount of calcium carbonates in soil and depends solely on the amount of soil to be replaced. So, one has to know in advance the value of $(\mathrm{S} / \mathrm{B})_{\mathrm{u}}$ in order to use the formula. The ratio $(\mathrm{S} / \mathrm{B})_{\mathrm{u}}$ may be obtained from local survey information if such information exist.

\section{CONCLUSIONS}

Calcareous soil is similar to gypseous soil in which both belong to the category of problematic soils/ collapsible soils. In Iraq gypseous soils are much available in middle and north of country, but calcareous soils are not much speared in Iraq. Soil replacement 
technique is one of the methods used to improve the strength properties of soils existing in a site. If depth of soil to be replaced is large then the method becomes impractical and needs both large finance and heavy equipment. The study is concerned in replacing the calcareous soil underneath footing by sand and observes the settlement obtained. A laboratory model is used for that. The depth of soil replaced and the settlement are normalized in terms of footing width B. It concluded that:

1. Laboratory results revealed that upon replacing a depth of $B / 2$ the degree of improvement (DOI) measured is 0.36 ; for replacing $\mathrm{B}, \mathrm{DOI}$ is 0.65 ; for replacing $2 \mathrm{~B}$, DOI is 0.88 ; and that for $3 \mathrm{~B}$, DOI is 0.92 .

2. It seems from recorded settlement results that the percentage of calcium carbonate present in sand has no appreciable effect on the improvement obtained using soil replacement technique if the applied soil stress is kept the same.

3. An empirical formula is derived relating DOI with depth of calcareous soil replaced. It can be used as a guide to predict the improvement factor in settlement in case of replacing a specified depth of calcareous soil.

\section{REFERENCES}

1. Olsen, J.M, and Leonard, B. D., (1982), "Strength of Compacted specimens of a Calcareous Playa Lake clay,” ASTM, STP 777, USA.

2. Chaney, R. C., and Slonim, S. M., (1982), "Determination of Carbonate Content in Soils" ASTM, STP 777, USA.

3. FAO/AGL, (2000), Land and Plant Nutrition Management Services, "ProSoil-Problem Soil Database" a net approach

4. Xin-Zhi Wang, Yu-Yung Jiao, Ren Wang, Ming-Jian Hu, Qing-Shan Meng, Feng-Yi Tan, (2011), "Engineering Characteristics of Calcareous Sand in Nan-sha Islands, South China Sea”, Engineering Geology, Vol.120, Issue 1-4, 10 June 2011, pp.40-47, Elsevier. (IVSL)

5. Al-Amoudi, Omar Saeed Baghabra, (1994), "Chemical Stabilization of Sabkha soils at high moisture contents" Engineering Geology, Vol. 36, Issue 3-4, April, pp.279-291, London

6. Yahia, E., Mohanedein, A., Al-Rawas, A., (2011), "Cement-Stabilization of Sabkha Soil from Al-Auzayba, Sultanate of Oman", Geotechnical and Geological Engineering. Nov.2011, Vol.29, Issue 6, pp.999-1008. (IVSL)

7. Stepho, A. S., (1989), “Some Engineering Properties of Stabilized Saline Soil- in Saudi Arabia” Engineering Geology, Vol. 26, Issue 2, January, pp.181-197, London. 
8. Stark, N., Wilkens, R., Emestsen, V. B., Lambers-Huesmann, M., Kopf, A., (2012),

"Geotechnical Properties of Sandy Sea Floor and Consequences for Dynamic Penetrometer Interpolation: Quartz Sand Versus Carbonate Sand", Geotechnical and Geology Engineering, Feb.2012, Vol.30, Issue 1, pp.1-14.(IVSL)

9. Rezaie, M., Ajalloeian, R., Ghefoori, M., (2012), "Geotechnical Properties of Problomatic Soils Emphasis on Collapsible Cases" International Journal of Geosciences, Feb. 2012, 3, 105-110, Isfahan, Iran. (IVSL).

10. Das, Braja M., (2008), “Advanced Soil Mechanics”, 3rd edition, Taylor and Francis, London.

11. Lambe, T. William, and Whitman, V. Robert, (1979), "Soil Mechanics", 2nd edition, SI Version, John Wiley and Sons, New York, USA.

12. Wilun, Zenon and Starzewski, Krzysztoff, (1975), "Soil Mechanics in Foundation Engineering" Surry University Press Great Britain.

13. Craig, Robert F., (2004), “Craig Soil Mechanics” Spon Press, Taylor and Francis Group. London.

14. Bowles, Joseph E., (1981), "Engineering Properties of Soils and their Measurements" $2^{\text {nd }}$ edition, McGraw-Hill, Kogakusha Ltd. 
Table (1): Extent ('000s ha) of soil groups by continent. (FAO/AGL), 2000.

\begin{tabular}{|l|r|r|r|r|r|r|r|r|}
\hline \multicolumn{1}{|c|}{ \#\# } & Africa & Australasia & Europe & $\begin{array}{c}\text { North } \\
\text { America }\end{array}$ & $\begin{array}{c}\text { North } \\
\text { and C. } \\
\text { Asia }\end{array}$ & $\begin{array}{c}\text { South } \\
\text { and C. } \\
\text { America }\end{array}$ & $\begin{array}{c}\text { South } \\
\text { and SE } \\
\text { Asia }\end{array}$ & Total \\
\hline Acrisols & 92728 & 32482 & 4170 & 114813 & 148241 & 341161 & 263005 & 996600 \\
\hline Arenosols & 462401 & 193233 & 3806 & 25512 & 3436 & 118967 & 94530 & 901885 \\
\hline Calcisols & 171237 & 113905 & 56657 & 114720 & 95264 & 24318 & 220068 & 796169 \\
\hline Ferralsols & 319247 & 0 & 0 & 0 & 0 & 423353 & 0 & 742600 \\
\hline Histosols & 12270 & 1167 & 32824 & 93462 & 99451 & 9245 & 24829 & 273248 \\
\hline Leptosols & 381531 & 48789 & 64836 & 83303 & 710863 & 246588 & 48789 & 1655318 \\
\hline Podzols & 11331 & 8459 & 213624 & 220770 & 21825 & 5522 & 5982 & 487513 \\
\hline Solonchaks & 48574 & 16565 & 2308 & 127 & 46895 & 24344 & 48512 & 187325 \\
\hline Solonetz & 13800 & 38099 & 7906 & 10748 & 30062 & 34652 & 0 & 135267 \\
\hline Vertisols & 106126 & 90019 & 5856 & 9120 & 11797 & 38076 & 76328 & 337322 \\
\hline
\end{tabular}

\#\# The morphological form of calcareous soil.

Table (2): Results of direct shear box for pure sand and 50\% calcareous sand.

\begin{tabular}{|l|l|l|l|l|}
\hline \multirow{2}{*}{$\begin{array}{l}\text { Vertical } \\
\text { stress } \\
\text { applied } \\
(\mathrm{kPa})\end{array}$} & $\begin{array}{l}\text { Alakheidher sand } \\
\text { hax. } \\
\text { horizontal } \\
\text { stress } \\
(\mathrm{kPa})\end{array}$ & $\begin{array}{l}\text { Angle of } \\
\text { internal } \\
\text { friction } \\
\Phi(*)\end{array}$ & $\begin{array}{l}\text { Max. } \\
\text { horizontal } \\
\text { stress } \\
(\mathrm{kPa})\end{array}$ & Angle of internal friction $\Phi(* *)$ \\
\hline 50 & 35 & 35 & 36.3 & 36 \\
\hline 75 & 52.5 & 35 & & \\
\hline 100 & & & 65 & 33 \\
\hline 200 & 125 & 32 & & \\
\hline 250 & & & 144 & 30 \\
\hline
\end{tabular}

Note:

(*) Best fit for $\Phi$ is 35 degrees

(**) 1- Best fit for $\Phi$ is 33 degrees

2- Each is an average of two tests, (thus totaling of six tests) 
Table (3): Time versus (S/B) ratio for different depths of soil replacements due to calcium carbonates content of $50 \%$ by weight.

\begin{tabular}{|l|l|l|l|l|l|}
\hline Time $($ minutes $)$ & $(\mathrm{S} / \mathrm{B})_{\mathrm{u}}$ & $(\mathrm{S} / \mathrm{B})_{(\mathrm{B} / 2)}$ & $(\mathrm{S} / \mathrm{B})_{\mathrm{B}}$ & $(\mathrm{S} / \mathrm{B})_{2 \mathrm{~B}}$ & $(\mathrm{~S} / \mathrm{B})_{3 \mathrm{~B}}$ \\
\hline $0.1=6$ seconds & 0 & 0 & 0 & 0 & 0 \\
\hline 1 & 0.031 & 0.017 & 0.010 & 0.005 & 0.002 \\
\hline 5 & 0.049 & 0.030 & 0.023 & 0.011 & 0.005 \\
\hline 10 & 0.056 & 0.038 & 0.027 & 0.012 & 0.006 \\
\hline 30 & 0.069 & 0.056 & 0.036 & 0.013 & 0.007 \\
\hline $60=1$ hour & 0.080 & 0.065 & 0.040 & 0.014 & 0.008 \\
\hline $1440=1$ day & 0.106 & 0.086 & 0.054 & 0.021 & 0.010 \\
\hline $2880=$ 2days & 0.147 & 0.112 & 0.078 & 0.024 & 0.016 \\
\hline $4320=$ 3days & 0.194 & 0.154 & 0.094 & 0.027 & 0.021 \\
\hline $7200=$ 5days & 0.293 & 0.200 & 0.104 & 0.036 & 0.024 \\
\hline $8640=$ 6days & 0.300 & 0.201 & 0.105 & 0.036 & 0.024 \\
\hline $10080=1$ week & & & & & \\
\hline
\end{tabular}

Table (4): Final (S/B) ratios obtained after one week of leaching for different depths of soil replacements and for three percentages of $\mathrm{CaCO}_{3} \%$.

\begin{tabular}{|l|l|l|l|l|l|}
\hline$\% \mathrm{CaCO}_{3}$ & $(\mathrm{~S} / \mathrm{B})_{\mathrm{u}}$ & $(\mathrm{S} / \mathrm{B})_{(\mathrm{B} / 2)}$ & $(\mathrm{S} / \mathrm{B})_{\mathrm{B}}$ & $(\mathrm{S} / \mathrm{B})_{2 \mathrm{~B}}$ & $(\mathrm{~S} / \mathrm{B})_{3 \mathrm{~B}}$ \\
\hline 30 & 0.15 & 0.096 & 0.060 & 0.015 & 0.0105 \\
\hline 50 & 0.30 & 0.201 & 0.105 & 0.036 & 0.024 \\
\hline 70 & 0.38 & 0.228 & 0.114 & 0.0456 & 0.0266 \\
\hline
\end{tabular}

Table (5): Degree of improvement recorded versus different depths of soil replacements and three percentages of $\mathrm{CaCO}_{3} \%$.

\begin{tabular}{|c|c|l|l|l|}
\hline$\%_{\mathrm{CaCO}_{3}}$ & $(\mathrm{~S} / \mathrm{B})_{(\mathrm{B} / 2)}$ & $(\mathrm{S} / \mathrm{B})_{\mathrm{B}}$ & $(\mathrm{S} / \mathrm{B})_{2 \mathrm{~B}}$ & $(\mathrm{~S} / \mathrm{B})_{3 \mathrm{~B}}$ \\
\hline 30 & 0.36 & 0.60 & 0.90 & 0.93 \\
\hline 50 & 0.33 & 0.65 & 0.88 & 0.92 \\
\hline 70 & 0.40 & 0.70 & 0.88 & 0.93 \\
\hline
\end{tabular}




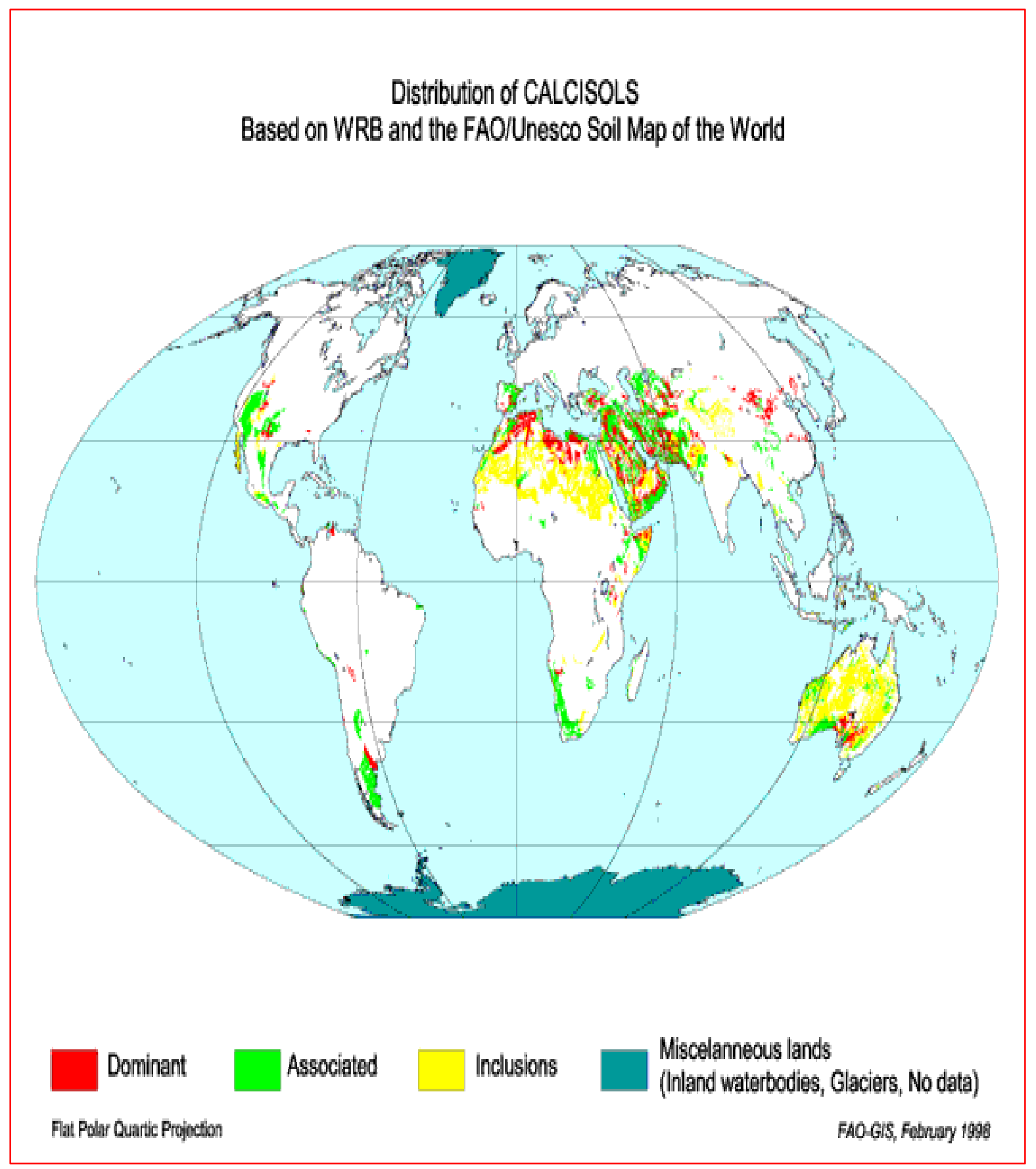

Figure (1): Approximate distribution of calcareous soils in world/ after FAO. 


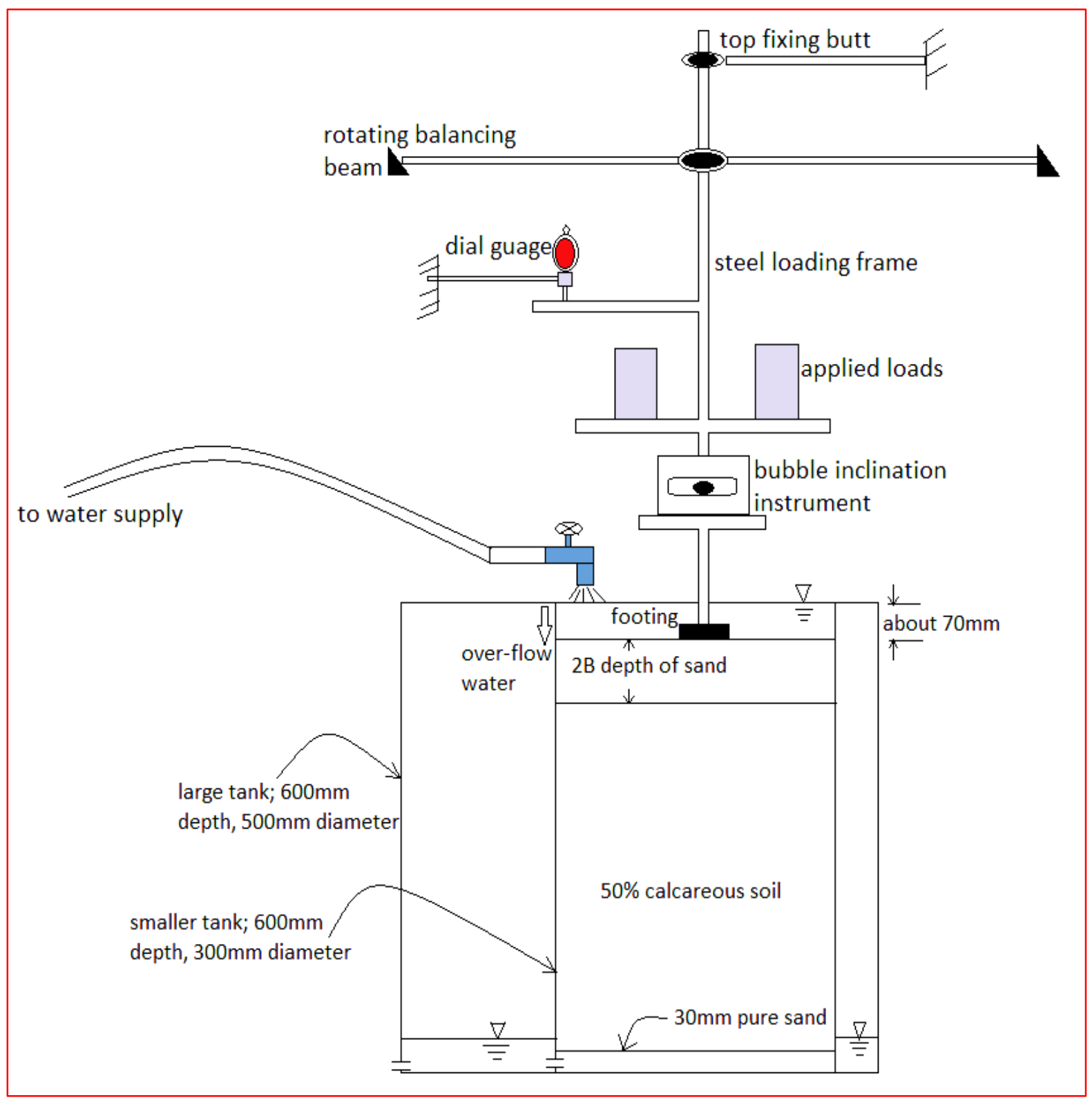

Figure (2): Representative drawing showing setup used in laboratory testing. 
Time in minutes

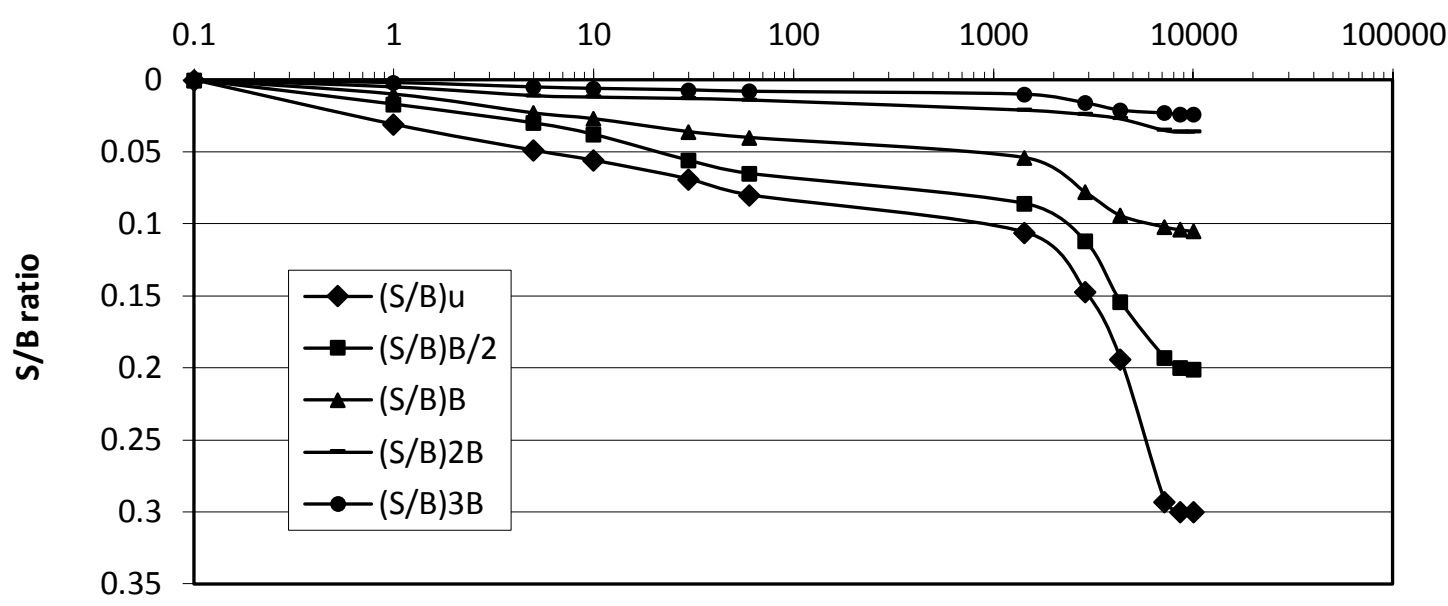

Figure (3): Time versus S/B ratios for different depths of soil replacements of 50\% calcareous soil.

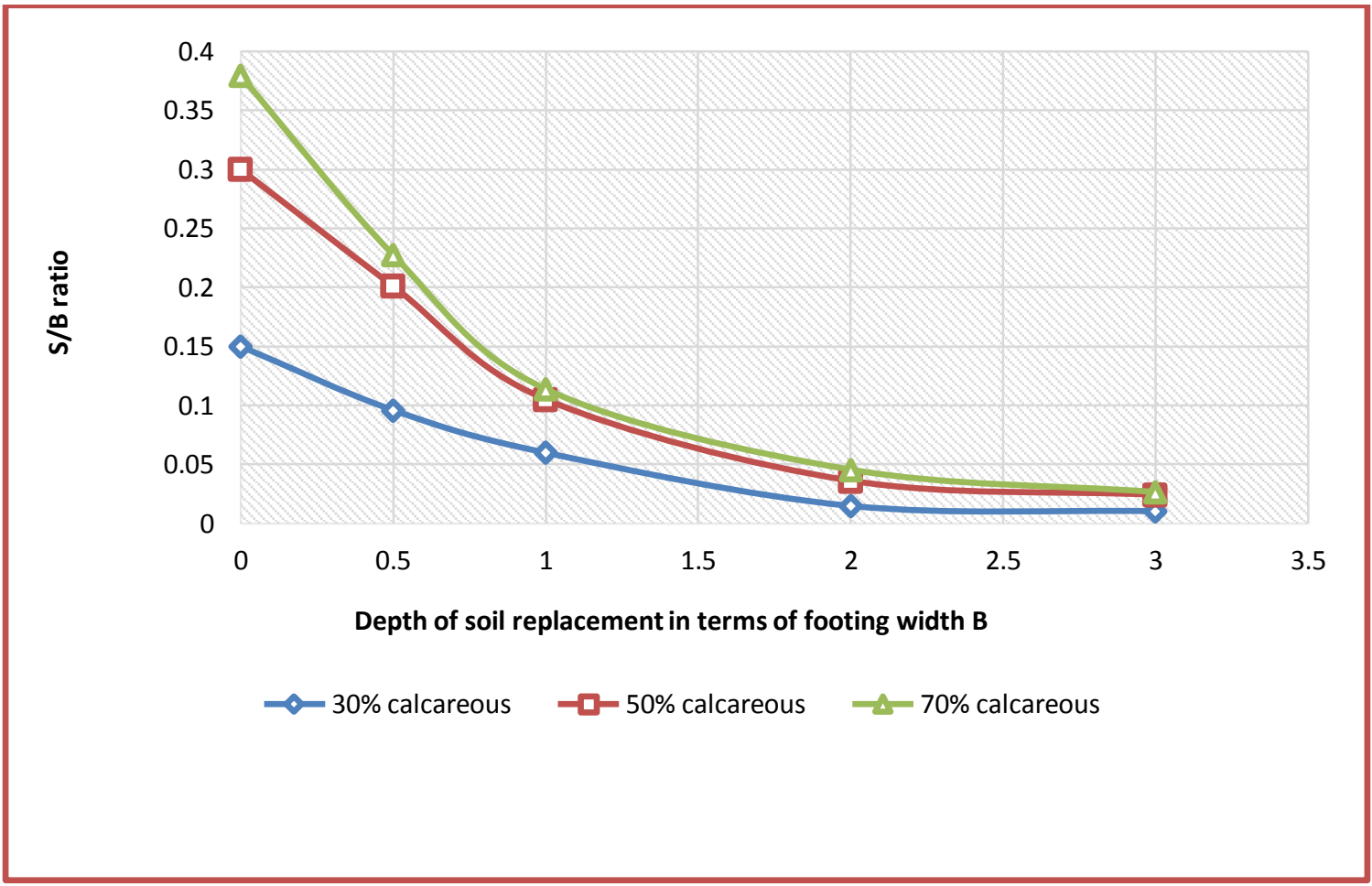

Figure (4): Final S/B ratios measured after one week of leaching for different depths of soil replacements and for three percentages of calcium carbonates. 


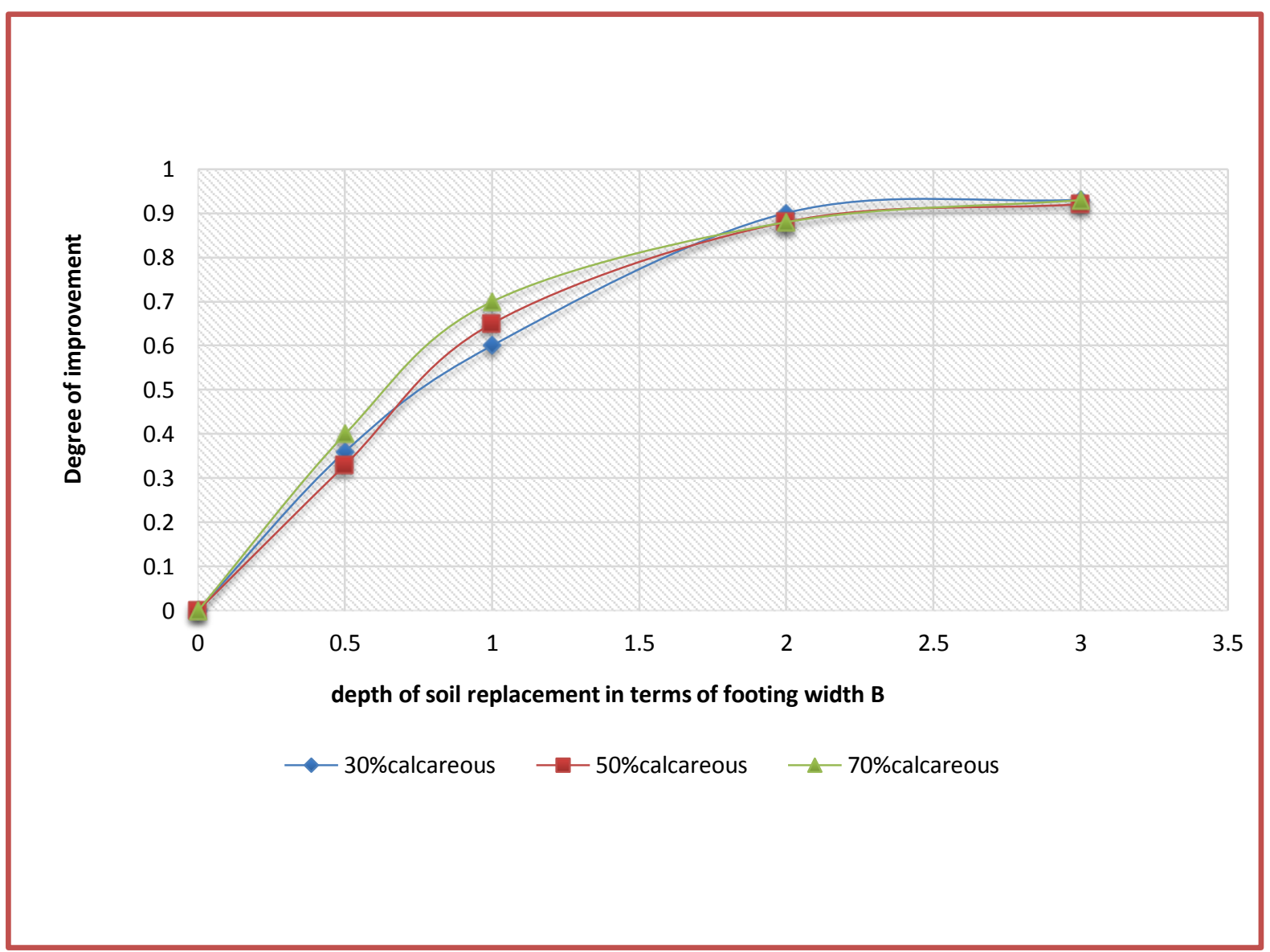

Figure (5): Degree of improvement measured versus different depths of soil replacements and for three percentages of calcium carbonates. 


\title{
تأثير استبدال التربة على انهيارية اساس فوق رمل كلسي -دراسة بنموذج رياضي
}

\author{
وعد عبد الستار حسين \\ استاذ مساعد / كلية الهندسة / جامعة ديالى على على
}

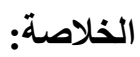

ان طريقـة اسـتبدال التربـة لغـرض تحسـين طبقـة تربـة ضـعيفة الخـواص ليسـت طريقــة حديثـة. وحيـث ان

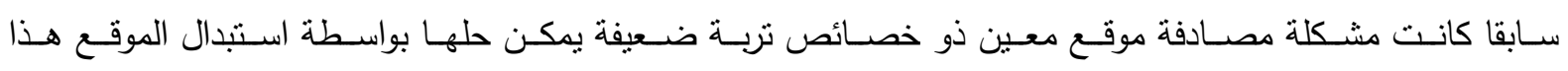

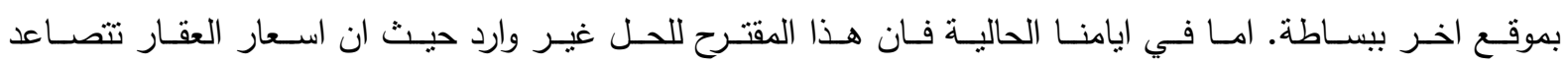

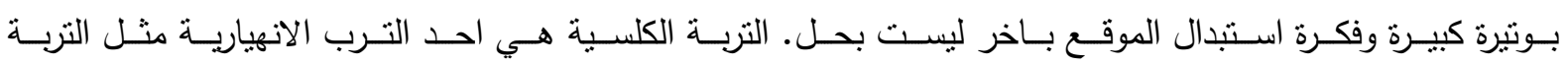

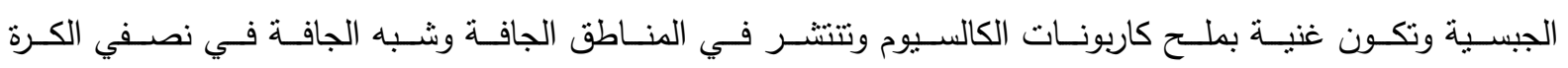

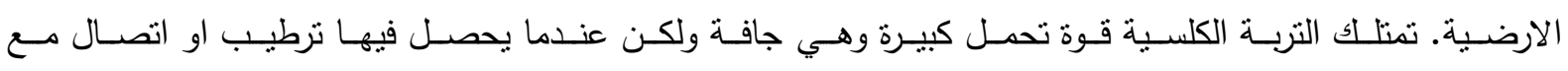

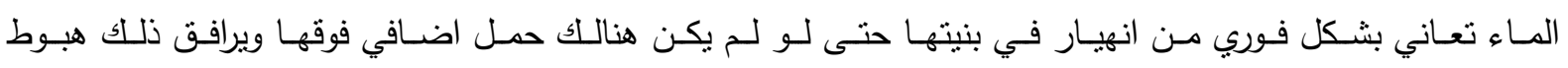

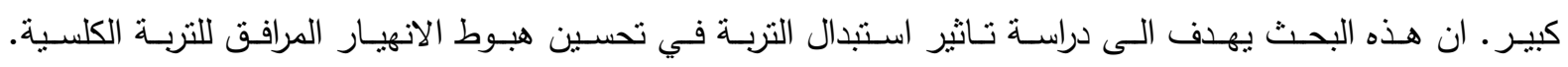

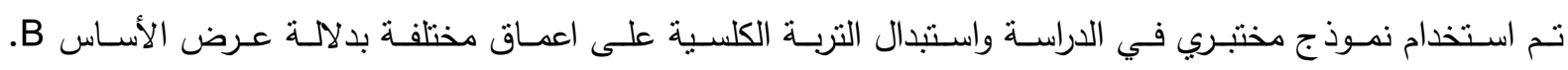

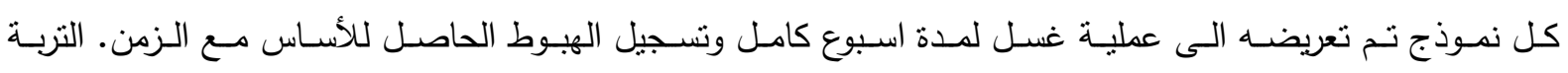
الكلسية المستخدمة هي رمل تم مزجه بكلس بنسب مختلفة.

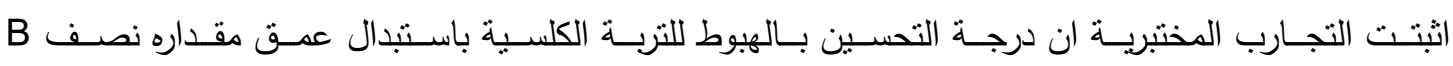

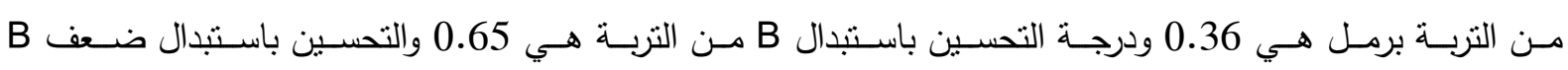

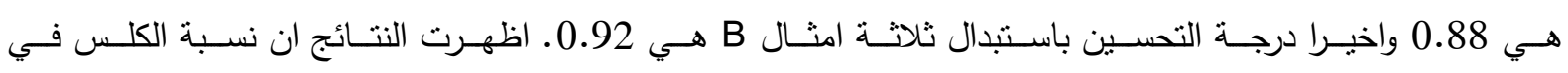

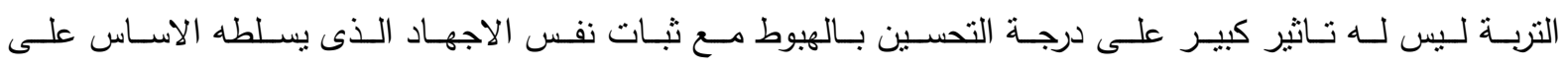

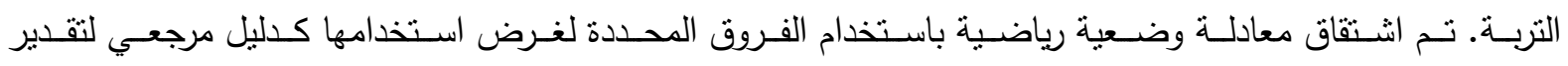
درجة التحسين في الهبوط للتربة الكلسية في حال استبدال عمق معين من التربة تحت الاساس. 